拡大肝左葉切除を行った胆管細胞癌の 1 例

\begin{tabular}{llllll}
\multicolumn{8}{c}{ 名古屋大学医学部第 1 外科 } \\
早川 & 直和 & 神谷 & 順一 & 中神 & 二人 \\
安井 & 健三 & 宮田 & 完志 & 向山 & 憲男 \\
杉浦 & 純一 & 犬飼 & 偉経 & 豊田 & 澄男 \\
松本 & 隆利 & 鈴木 & 雄彦 & 二村 & 雄次 \\
服部 & 龍夫 & 弥政洋太郎 & &
\end{tabular}

\title{
A CASE OF CHOLANGIOCARCINOMA RESECTED WITH THE EXTENDED LEFT HEPATIC LOBECTOMY
}

\section{Naokazu HAYAKAWA, Junichi KAMIYA, Kazuhito NAKAGAMI, Kenzo YASUI, Kanji MIYATA, Norio MUKOHYAMA, Junichi SUGIURA, Hidenori INUKAI, Sumio TOYOTA, Takatoshi MATSUMOTO, Takehiko SUZUKI, Yuji NIMURA, Tatsuo HATTORI and Yohtaro IYOMASA}

First Department of Surgery, Nagoya University School of Medicine, Nagoya

案引用語：胆管細胞癌, 拡大肝左葉切除, 肝動脈造影, aircholangiogram

\section{はじめに}

最近の診断技術の進歩に伴い，肝胆道系の悪性腫演が 割合早期に䛦断できるようになり，それによって切除可 能例も增加しつつある. しかし, 胆管細胞癌は原発性肝 癌の範俦に入り，一般に肝内の細胆管枝より発生するた め肝門部浸潤が波及するまで黄疾を来すことなく進行 し，腫癔を触知したり，黄疸出現時には切除不能となる ことが多い.今回われわれは黄㾞を主訴として来院し, 術前の諸検查にて胆管細胞癌を強く疑い，拡大肝左葉切 除にて根治術を施行出来た症例を経験したので，その診 断，手術術式について若干の考察を加えて報告する.

\section{症例}

患者：43歳 女性

主訴 : 黄疸

既往歴，家族歴：特記すべきことなし。

現病歴：1979年 6 月初旬, 黄疸出現, 食欲不振にて近 医を受診し肝炎の診断にて投薬を受けたが黄疸が軽減し ないため他医へ紹介された。経皮経肝胆道造影（以下 PTC と略す), 腹腔動脈造影などにて肝門部胆管癌の診 断を受け，経皮経肝胆道ドレナージ（以下 PTCD と略 す）を施行の後，1979年 8 月20日手術のため当科を受診
した. 初診時理学的所見 : 眼球結膜に黄疸著明, 眼䀫結膜に 貧血はなく, 肝は右季胁下に右乳上に25横指触知した. 初診時検查所見: 血清ビリルビンは $6.3 \mathrm{mg} / \mathrm{dl}$ と高值 を示し，GOT, GPT は僌度上昇しアルカリフォスファ ターゼ, $\alpha$-フェトプロティンは正常值を示し, HB 抗原 は陰性であった（衰1）。

\section{表 1 初診時検査成績}

\begin{tabular}{|c|c|c|c|c|c|}
\hline WBC & $5.4 \times 1$ & $10^{3}$ & T.bil. & 6.3 & $\mathrm{mg} / \mathrm{dl}$ \\
\hline RBC & 3.78 & $\times 10^{6}$ & D.bil. & 3.2 & $\mathrm{mg} / \mathrm{d} \boldsymbol{d}$ \\
\hline $\mathrm{Hb}$ & 12.2 & $g / d e$ & TTT & 2 & u. \\
\hline $\mathrm{Ht}$ & 35.4 & $\%$ & ZTT & 4 & u. \\
\hline T.P. & 7.9 & $g / \mathrm{d} \ell$ & $\mathrm{Na}$ & 138 & $\mathrm{mEq} / \mathrm{l}$ \\
\hline Alb. & 3.8 & $g / \mathrm{d} \ell$ & $k$ & 5.0 & $\mathrm{mEq} / \mathrm{l}$ \\
\hline GOT & 72 & u: & $\mathrm{Ca}$ & 4.7 & $\mathrm{mEq} / \mathrm{l}$ \\
\hline GPT & 48 & $u$. & $\mathrm{Cl}$ & 102 & $\mathrm{mEq} / \ell$ \\
\hline Al-P & 5.5 & KAu. & HB-Ag & & $(-)$ \\
\hline LDH & 220 & u. & ICG-K & 0.131 & \\
\hline Ch-E & 0.95 & $\Delta \mathrm{pH}$ & AFP & 1.0 & $\mathrm{ng} / \mathrm{m \ell}$ \\
\hline T.Chol & 275 & $\mathrm{~m} / \mathrm{d} \ell$ & S-Amyl & 101 & u. \\
\hline
\end{tabular}


胆道X線検查所見 : PTCD カテーテルからの胆道造影 にて右肝内胆管は著明に払張し，肝門部胆管は不整な㹟 窄像を像を呈して打り，左肝内胆管は造影されなかっ た. 肝門部胆管癌と訩断した（図 1)。また，内視鏡的 逆行性胆管造影々の併用による胆道はさみらち造影では 左肝内胆管は左右肝管分岐部より左葉中央部にかけて辺 縁平滑な狭窄像を示しており，肝門部においては右肝 管，および総肝管も同様の所見を呈しており，尰場は肝 左葉中央部より肝門部に及んでいると考えられた（図 2 ).

\section{図 1 経皮経肝胆道造影}

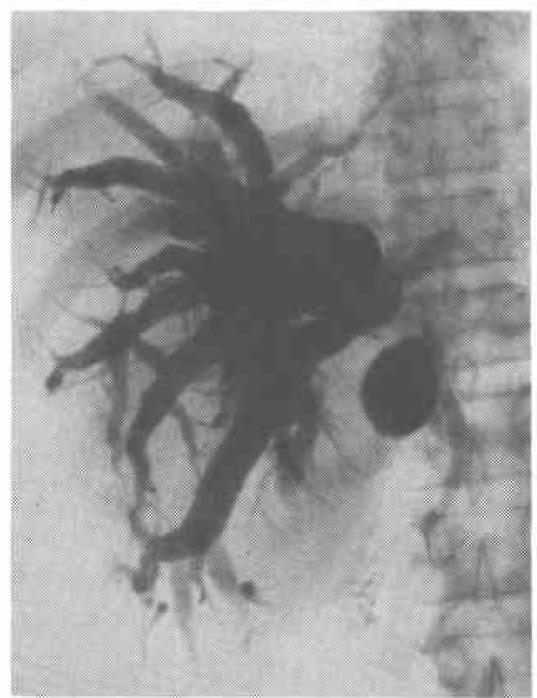

右肝内胆管の拡張，肝門部胆管の不整な狭窄像を認 めた。左肝内胆管は造影されなかった。

血管造影所見 : 左肝動脈は左肝内胆管の狭窄部と思わ れる部において, encasement, occulusion を示し,この 部に hypovascular な腫煌が存在すると考兄られた. 同 時に行った aircholangiogram に拈忊る右肝管，総肝管 の病変部には右肝動脈の異常所見がなく，隀瘍は鎌状靬 帯付近の肝内胆管に原発し，肝門部へ浸潤したものと考 え，左肝内胆管より発生した胆管細胞癌を強く疑った （図 3)。また，同時に行った上腸間膜動脈造影の門脈相 飞おいて左門脈に encasement がみられたが右門脈には 異常所見はみとめられなかった（図4）.

手術所見打よび手術術式 : 以上の諸検査より切除可能 之判断し，1979年 9 月 27 日手術施行，両側季肋下部切開 にて開腹, 肝左葉は萎縮し，腫場は左葉内側区域から
困 2 胆道はさみらち造影

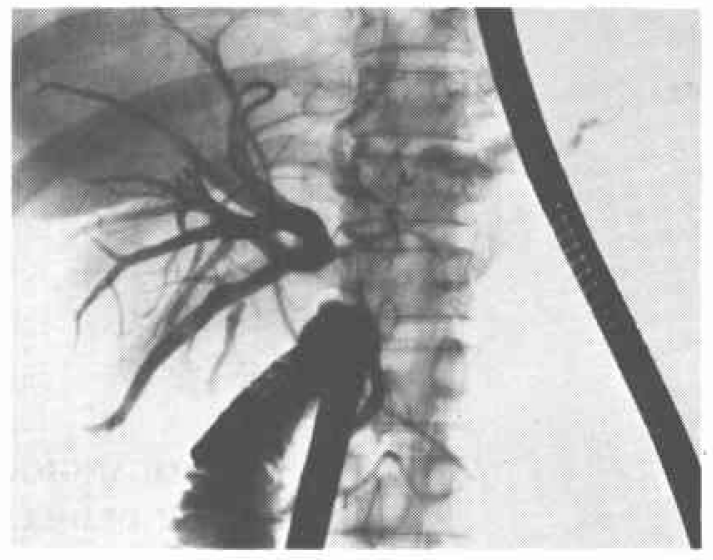

左肝内胆管は左右肝管分枝部より左葉中央部にかけ て辺縁平滑な狭窘像を示しており，肝門部における 右肝管，総肝管にも同様の所見を訆めた。

\section{図 3 総肝動脈造影}

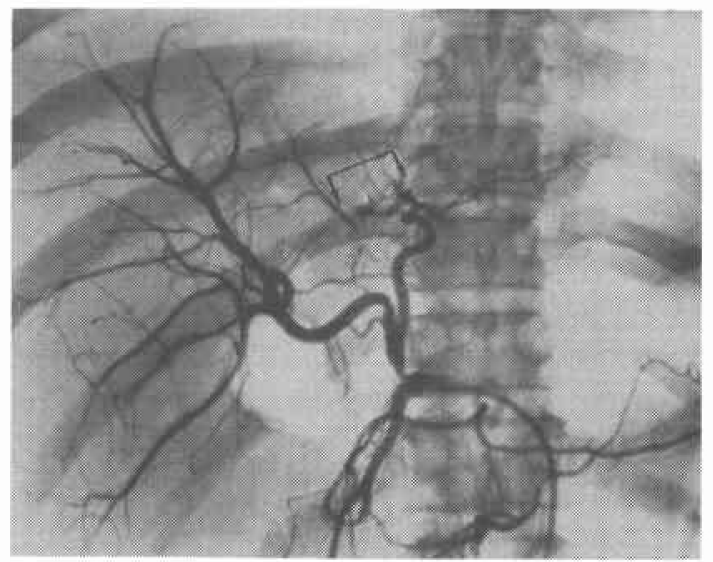

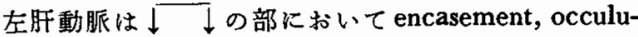
sionを認めた。

Cantlie 線をわずかにこえてくるみ大の硬化部を触れる のみであり, 他汇根治術を妨げる要素はなく, 根治術可 能と判断した. 肝門部で左肝動脈, 左門脈を結禁切離 し，ついで肝静脈を露出し左肝静脈，中肝静脈は根部で 結禁切離した。ついで Cantlie 線をこえて右肝静脈に 沿って右葉前上区域を一部ふくめて切除した．再び肝門 部にもどり右肝内胆管は前後枝分枝部をこえてさらに上 流胆管まで露出し，後枝は上下枝の分枝部まで露出して この部で切離する桩大肝左葉切除を施行した，再建は Roux一Y 吻合による右肝管前枝, 後枝と空腸吻合を行 
図 4 上腸間膜動脈造影静脈相

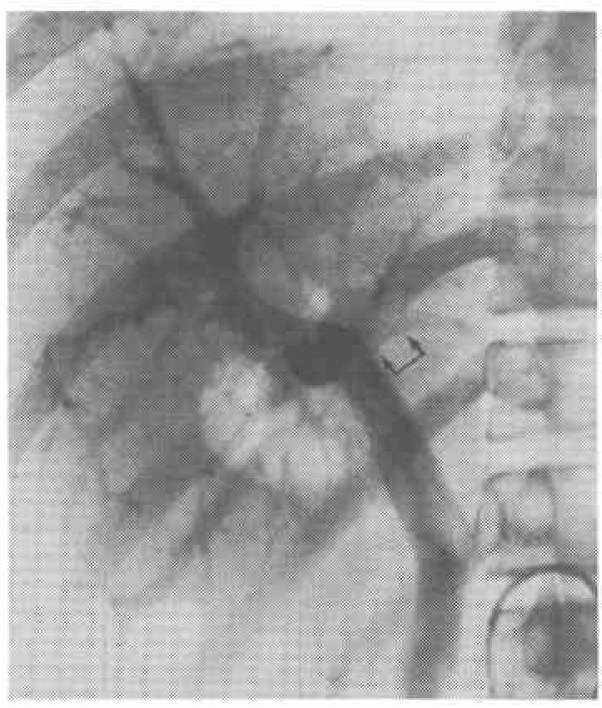

左門脈の】」の部に encasementを認めた。

図 5 術中写真

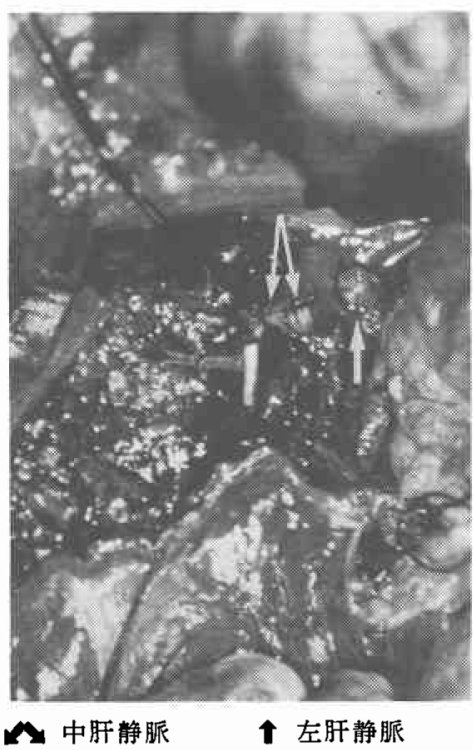

った（図 5，6）切除肝重量は $205 \mathrm{gr}$ であった. 術後 経過は良好で術後33日で退院した。

切除標本造影所見 : 左肝内胆管は腫瘤部に一致して周 辺よりのしめつけ型の狭窄像を示していた，左葉内側区 域の肝内胆管枝にす同様の所見がみられた（図 7). 切除標本肉眼所見：腫煬は黄白色で硬く，一部結節状
図 6 手術術式

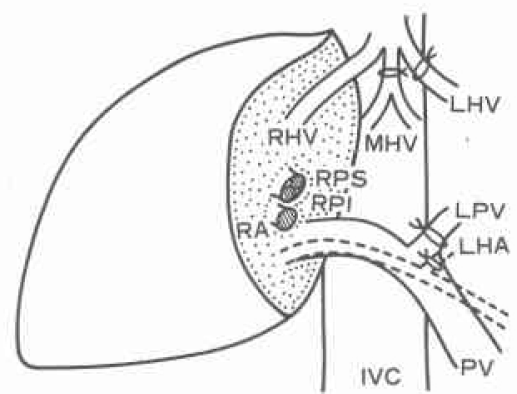

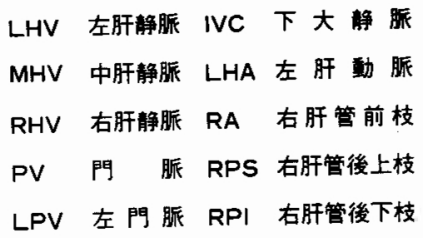

图 7 戓除樏本浩斯

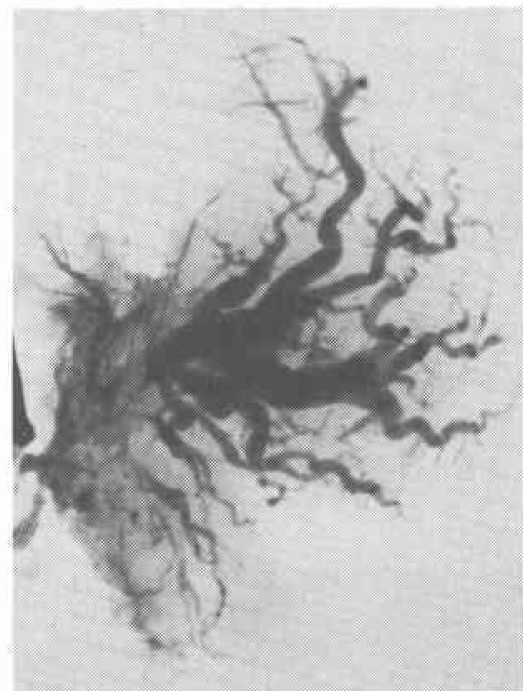

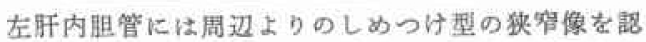

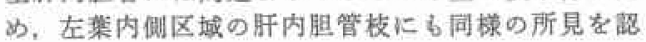
めた。

であるが多くは浸潤性であり，肝門部には腫癉塊はみら れなかった。腫瘤より切離面までの肉眼的距離は最短 $7 \mathrm{~mm}$ であった (図8).

病理組織学的所見 : 腫瘤は $30 \times 30 \mathrm{~mm}$ で左葉の実質内 を占め, 小腺管を形成して增殖し, 周囲の肝実質とよく なじんだ配列をなしておりこの部に原発した胆管細胞癌 
図 8 切除標本

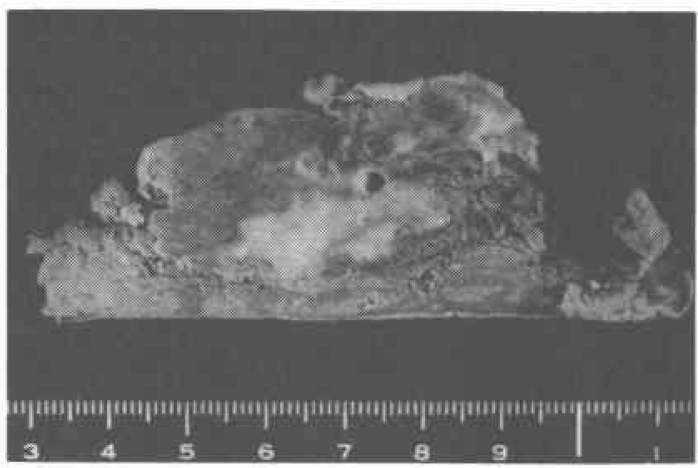

稙痬中心部の割面は黄白色で硬い嗹瘤を認めた。

と診断した（図9a).さらに神経線維，および胆管に 沿った浸潤が著明で，特に右主肝管周囲にも結合織の増 生が著明で腫湯細胞の増殖がみとめられた（図9b).

\section{考察}

頻度 : 胆管細胞癌は原発性肝癌の範涛に入り全肝癌の 10〜20\%を占めるといわれている(2)3)4. また，全胆管 癌に対する頪度もほぼ同様と報告されている(5)6)7)，男女 比は肝緗胞癌が圧倒的に男子に多いのに比べて，胆管細 胞癌は男女ほぼ同数であり，これは諸家の報告が一致す

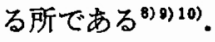

診断, 切除率 : 胆管細胞癌は一般に肝内の細胆管枝よ り発生し，肝門部胆管に浸潤が波及するまで黄庭を来す

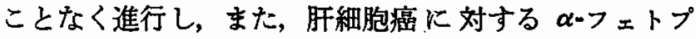
ロティンの如き特異的な検査法むないので，腫瘤を触知 したり，黄疸出現時には切除不能となることが多く，本
邦報告例においてす切除率は肝細胞癌よりやや劣ってい

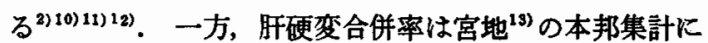
よれば肝細胞癌64〜91\%であるのに対して, 胆管細胞癌 は7.1〜36\%と低い. また, 諸家に括いて子同様の報告 がなされている(14)15)。したがって，腫慮触知や黄疸出 現以前に発見されたものは切除可能例が多いと考えられ る.したがって内視鏡的逆行性䏣管造影，CT スキャ ン，超音波撮影，血管造影などを駆使して早期診断に努 めることが肝要である.ささいわい. 本症例は黄疾出現後 であったが, PTCD カテーテルよりの aircholangiogram と血管造影を組合わせることにより，腫場原発部位お よび浸鬫範囲を診断し, 切除可能と術前診断出来た. aircholangiogram と血管造影の組合わせは resectability の診断には有効であった.今後症例を重ね検討を要する 診断法の1つであろう.

扗大肝左葉切除について：肝切除の手術々式は従来の 解剖学名に準拠するすのと, 近年の肝内脈管系の走行分 岐を考虑した肝区域に従うすのがある(16)17)18)19)20)。広 箅囲の肝切除においてその切除肝の量に対する呼び名に は広沉肝右葉切除 ${ }^{21)}$ ，払大肝右葉切除 ${ }^{22)}$ ，右側三区域切

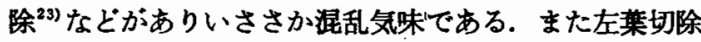
については，左葉切除と左側三区域切除の中間の術式に 対する呼び名が見あたらない：これらに対してのわれわ れの見解は肝切除を安全に行らにはやはり脈管の走行に 準拠した肝区域にしたがうのが妥当であると考えてい る.したがって右葉と左葉内側区域を切除したものは右 側三区域切除であり，Cantlie 線まで切除したものは右 葉切除であり，Cantlie 線をこえて切除を行らが切除さ

図 9 病理組嬂像

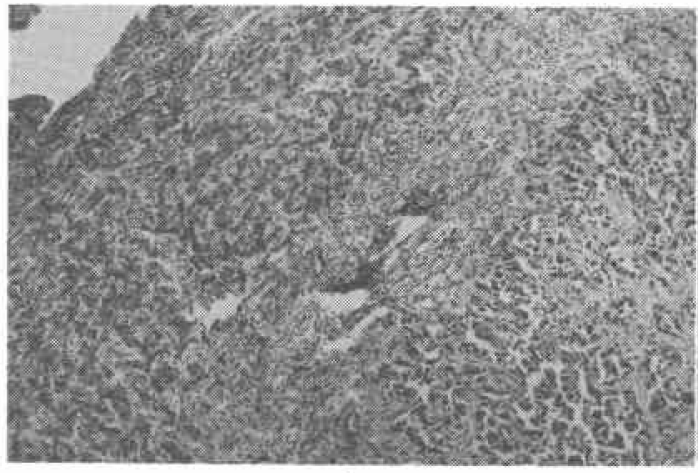

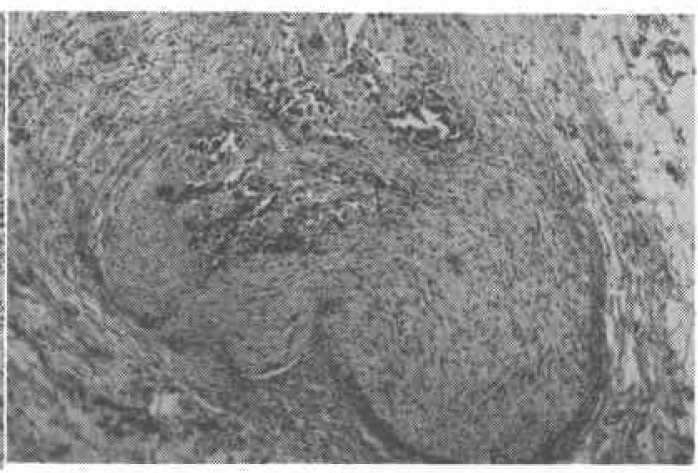

b

畽蜴細胞は小腺管を形成して增殖し周囲肝実質とよくなしんだ配列を示した（a). 著明な神経線䑾浸潤を 認めた（b). 
れる三区域目すなわち左葉内側区域の切除量にはこだわ らない呼び名が拡大右葉切除之考克ている. 今回われわ れの呼んだ拡大肝左葉切除は肝臓手術の成書にはみられ ない言葉であるが上記右葉切除に対するわれわれの概念 にしたがって名付けたすすなわ左側三区域切除と左葉 切除の中間の術式で，切除される三区域目すなわち右側 区域の肝の容量にこだわらない術式と考えている. 今 後，肝区域にしたがった術式が増加するにしたがい今回 われわれの行った術式の如く従来の名称では包含できな い術式が增加するであるうが，桩大肝左葉切除はこれら の多くを含みらる呼び名と考えている.

\section{結語}

術前に腫㵣の原発部位，浸潤範囲，resectability が䛦 断でき，左側よりCantlie 線をこえて右葉前上区域を一 部切除する払大肝左葉切除術にて切除可能であった胆管 細胞癌の 1 例を報告し若干の文献的考察を加えた.

（本論文の要旨は第 192回東海外科学会において発表 した。 )

\section{养考文献}

1) 宮地 徽 : 肝癌の病理. 最新医学, $11: 1847$ 一 $1853,1956$.

2) 石川浩一：原発性肝癌症例に関する追跡調査一 第 3 報一。肝䐘, 17 ：460-465，1976.

3) McBride, C.M.: Primary carcinoma of the liver. Surg., 80: 322-327, 1976.

4) 葛西洋一ほか：原発肝癌の外科的治療。外科診 療, $19: 46-55,1977$.

5) Kuwayti, K., et al.: Carcinoma of the major intrahepatic and the extrahepatic bile ducts exclusive of the papilla of Vater. Surg. Gynecol. Obstet., 104: 357-366, 1957.

6) 黒柳弥䓓雄注か：胆管癌の外科治療。外科, 35: $391-401,1973$.

7) 木南義男ほか：肝内および肝門部胆管癌の手術 成續と胆管癌多発例における臨床像の検討。日
消外会誌，12：908一-913，1979.

8) MacDonald, R.A.: Primary carcinoma of the liver. A.M.A. Arch. Intern. Med., 99: 266$279,1957$.

9) 本庄一夫ほか：肝癌の外科治療。日本臨床, 25: 2353-2359, 1967.

10) 木南義男注：原発性肝癌に対する外科治療の 成績。日癌治，9:44一50, 1974 。

11）本庄一夫ほか：原発性肝癌の治療経験。日本臨 床, $29: 2297-2305,1971$.

12）佐藤寿雄ほか：原発性肝癌の治療について一自 験例を中心として一。外科、35：969-975， 1973.

13）宮地 徹浪か：最近10年間におけるわが国の原 発性肝癌一病理学的研究一。肝臓, $1: 17-36$, 1960.

14）有馬道雄：原発性ならびに転移性肝癌の臨床知 見補遗。肝藏， 7：224-247，1966。

15) 海藤 勇ほか：新内科学大系, 肝腯場。23 : 313-356, 中山書店, 東京, 1977 .

16) Hjortsjö, C.H.: The topography of the intrahepatic duct systems. Acta Anat., 11: 599615,1950 .

17) Brunschwig, A.: With special reference to secondary malignant neoplasms. Cancer, 6: 725-742, 1953.

18)三上二郎汪品：肝茂の手術。日本外科手術全 書, 8, 日本外科手術全書刊行会, 東京, 1959 .

19) 水户䌷郎：肝腫瘍。新日本内科学大系, 23 : 357-386, 中山書店, 東京, 1977 .

20) 葛西洋一注か：肝・胆・膵の外科臨床，医学書 院、東京, 1979 .

21) 三上二郎：肝広汎切除。日外会誌，57：898一 $921,1956$.

22) Pack, G.T., et al.: Regeneration of human liver after major hepatectomy. Surg., 52: 617$623,1962$.

23) Starzl, T.E., et al.: Hepatic trisegmentectomy and other liver resections. Surg. Gynecol. Obstet., 141 : 429 437, 1975. 